\title{
Teachers' Perceptions Towards Digital-Based Teaching Material
}

\author{
Ayu Istiana Sari ${ }^{1}$, Nunuk Suryani ${ }^{1}$, Dewi Rochsantiningsih ${ }^{1}$, Suharno $^{1}$ \\ ${ }^{1}$ Universitas Sebelas Maret \\ Ir. Sutami 36 A, Kentingan, Surakarta, 57126, Jawa Tengah, Indonesia.
}

E-mail: ayuistianasari82@gmail.com

\begin{abstract}
The aims of this study are (1) to describe the English teachers' technical readiness towards digital-based teaching materials, (2) to describe the English teacher's attitude towards digital-based teaching material, (3) to describe the English teachers' obstacles towards the development of digital-based teaching materials, and (4) to describe the English teacher's perception on the procurement and development of digital-based teaching materials.

Qualitative methodology was used to collect and analyze the data obtained from all the respondents. The subjects of the research were the English teachers of Senior High School in Solo. The data collection used in this research was questionnaires and interviews. The questionnaire was specifically designed to answer research objectives related to teachers' perceptions of the use of ICT in Senior High Schools in Solo. In analyzing the data, the researcher used qualitative analysis of interactive models.

The results reveal that the English teacher's readiness towards digital-based teaching materials is only slightly more than neutral; another finding indicates that teachers have the desire to integrate digital-based teaching materials effectively in the classroom. It can be concluded that the English teacher at senior High School in Solo need intensive training in the use of the digital-based teaching materials to fully support the teaching and learning process.
\end{abstract}

Keywords: teacher's perception; digital based; teaching material

\section{INTRODUCTION}

The use of ICT in education, including foreign language is a positive response to the development of information and communication in the third millennium. Therefore, the use of ICT in supporting language learning is a necessity, not only to improve the effectiveness and quality of learning, but more important is to increase the mastery of ICT for both teachers and students in a technological era that is constantly changing and developing.

In the context of language learning, the use of multimedia technology can improve the effectiveness and efficiency of learning, which is expected to provide public satisfaction by providing excellent service. Ghasemi dan Hashemi (2011), states that ICTs help English learners by allowing them to communicate quickly and flexibly. In addition, ICT can be used to integrate speaking, listening, reading and 
writing. It can increase learning motivation. It also expands students' ability to work independently.

One part of learning using ICT is the use of multimedia. Multimedia is a tool that can create dynamic and interactive presentations that combine text, graphics, animation, audio and video images. The definition of multimedia according to Suyanto (2003) is the use of computers to create and combine text, graphics, audio, motion pictures (video and animation) by combining links and tools that allow users to navigate, interact, create and communicate. One of the multimedia that can be used in learning is in the form of a digital book or ebook. Cornalia dan Tirocchi (2012), states that ICT has shifted education, broadening concept into the learning process: i.) Teaching materials have been enriched with multimedia content; ii) the quantity of textbooks and study content has increased significantly iii) sharing information and enabling wider interaction has encouraged the development of learning strategies. "There is a tendency to think that ICT is so "new" that its use will be accompanied by new pedagogies that will somehow transform teaching and learning" (Sutherland et al. 2004 : 413). Teachers not only learn how to use new technology, but also learn how to use and maximize it to support learning. ICT can help teachers to broaden students' perception and bring new opportunities to learn.

It can be concluded that ICT has the most effective contribution to learning. ICT helps English learners by enabling them to communicate easily. One of the utilization of ICT in learning English is through the use of digital-based teaching materials (E book). In line with Pinto, Pouliot and Garcia (2014),

"e-books offer for reaching vast sources of knowledge in the academic area as well as for stimulating the sensibility and sensitivity in the use of reading mobile devices (e.g. e-readers, tablets, cell phones and hybrids) and also online e-book platforms, especially digital libraries, to improve their skills to interact well in the new digital learning environment".

Kamgar dan Jadidi (2016) also states that "With the development of technology around the world, the quantity of texts available in various languages especially in English has increased". It requires learner to improve their reading ability and interact with different authentic material (Grabe \& Stoller, 2002). Huang, Chen, dan Ho (2014) emphasized that "The fresh reading system not only provides many innovative and attractive applications for digital reading but also interprets digital reading more properly with the brand-new context of use.

Based on the description, it is important to know the perceptions of English teachers towards digital-based teaching material. The purpose of this study is to describe: (1) the English teachers' technical readiness towards digital-based teaching materials, (2) the English teacher's attitude towards digital-based teaching material, and (3) the English teachers' perceptions towards the development of digital-based teaching materials.

\section{RESEARCH METHODOLOGY}

This research was a descriptive qualitative research. This research has been conducted at senior high school in Solo. Seven senior high schools were selected. The sample of the study consisted of eight English teachers. The subjects of the research were the English teachers of Senior High School in Solo. The data 
collection used in this research was questionnaires and interviews. The data collected from the respondents were gathered together to be analyzed using qualitative analysis of interactive models.

The questionnaires were used to collect evidence from teachers about the experience and knowledge about the use of digital-based teaching materials, and their attitudes towards the use of digital-based teaching materials for teaching and learning English. The questionnaires used in this study are divided into 3 sections: (1) questionnaire about the level of teacher readiness on the utilization of digitalbased teaching materials in English learning, (2) questionnaires about teacher's attitude toward the utilization of digital-based teaching materials in English learning, and (3) questionnaire about obstacles faced by the in-service teachers in teachinglearning process. Interview is used to find out what the teacher thinks about the development of digital-based teaching materials.

\section{RESEARCH FINDINGS AND DISCUSSION}

The policy on the use of ICT written in the Regulation of Indonesia Ministry Education Number 65 of 2013a on the Standard of Primary and Secondary Education Process in paragraph 13 namely "the use if ICT to improve the efficiency and effectiveness of learning". Therefore, learning English facilitated by ICT will make the teachers and their learners ecome more effective. ICT also makes the learners easily manage their own learning activities so that they are able to maximize the usefulness of all learning resources.

The findings of this study indicate the level of teachers' readiness on the use of teaching materials based on technology and teachers' attitudes toward the use of technology-based teaching materials. In addition, the results of the interview was that teachers expected the development of digital-based teaching materials.

There are 3 types of questionnaires used by researchers, namely: (1) questionnaire to determine the technical readiness of English teachers in the use of digital-based teaching materials, (2) questionnaires to find out the attitude of English teachers towards the use and development of digital-based teaching materials, 3) a questionnaire to find out the barriers from the teachers when using digital-based teaching materials. 


\section{The English teachers' technical readiness towards digital-based teaching materials}

TABLE I. ENGLISH TEACHERS' TECHNICAL READINESS TOWARDS DIGITAL-BASED TEACHING MATERIALS

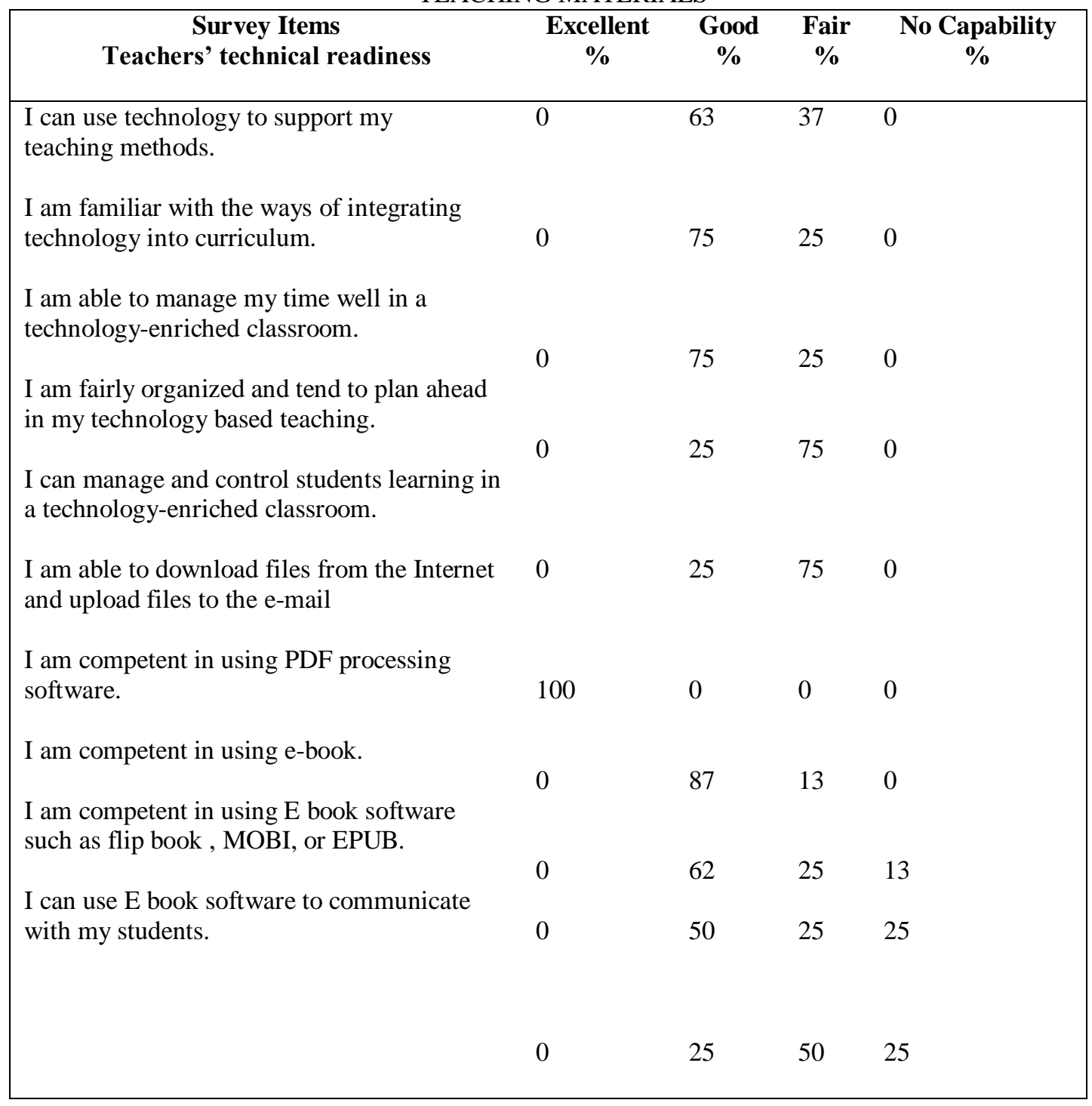

This table explores the English teachers' technical readiness towards digitalbased teaching materials. The respondents seemed to indicate that their readiness towards digital-based teaching materials is only slightly more than neutral, which implies that the English teachers of senior high school in Solo tend to accept the implementation of digital-based teaching materials prudently. It can be seen from the result that most of the participants can use technology to support teaching learning process. The respondents were competent in using PDF processing software but they seemed to learn more to use E book software such as flip book to communicate with their students. The result showed that $25 \%$ of English teacher of Senior High School had no capability to use E book software such as flip book to communicate with their students. In addition, factors such as those reported in this point should receive more attention. The successful implementation of digital-based teaching materials relies 
heavily on teachers' readiness and willingness to adopt technology (Singh \& Chan, 2014; Summaka, Baglibel, \& Saman-cioglu, 2010). Teachers can integrate digitalbased teaching materials to support the curriculum, facilitate teachers' work, and encourage student-centered learning (Ertmer, Ottenbreit-Leftwich, Sadik, Sendurur, $\&$ Sendurur, 2012). In order to be ready to integrate digital-based teaching materials in the curriculum, teachers must be provided with a solid foundation of knowledge and skills in digital media and develop new understandings, new approaches, new roles, new forms of professional development, and new attitudes about technology integration (Ruggiero \& Mong, 2015; Sabzian \& Gilakjani, 2013). They need intensive training in the use of the digital book to fully support the teaching and learning process. Teachers must have the technical and pedagogical skills to use technology and the willingness to integrate technology in their teaching (Gura \& Percy, 2005). Teachers' professional development programs should be designed to equip teachers with technical skills and pedagogical knowledge to implement the digital curriculum (Al-Awidi \& Aldhafeeri, 2017).

\section{English teacher's Attitudes towards digital-based teaching materials}

TABLE II. ENGLISH TEACHER'S ATTITUDES TOWARDS DIGITAL-BASED TEACHING MATERIALS

\begin{tabular}{|c|c|c|c|c|}
\hline $\begin{array}{l}\text { Survey Items } \\
\begin{array}{c}\text { Attitudes towards digital-based teaching } \\
\text { materials }\end{array}\end{array}$ & $\begin{array}{l}\text { Strongly } \\
\text { agree } \\
\%\end{array}$ & $\underset{\%}{\operatorname{Agree}}$ & $\begin{array}{l}\text { Disagree } \\
\%\end{array}$ & $\begin{array}{l}\text { Strongly } \\
\text { disagree } \\
\%\end{array}$ \\
\hline $\begin{array}{l}\text { It is very important to me to have a digital- } \\
\text { based teaching materials }\end{array}$ & 87 & 13 & 0 & 0 \\
\hline $\begin{array}{l}\text { I will use digital-based teaching materials } \\
\text { because I am very interested. }\end{array}$ & 87 & 13 & 0 & 0 \\
\hline $\begin{array}{l}\text { I will feel comfortable using digital-based } \\
\text { teaching materials as a tool in teaching and } \\
\text { learning. }\end{array}$ & 75 & 25 & 0 & 0 \\
\hline $\begin{array}{l}\text { A digital-based teaching material is a valuable } \\
\text { tool for teachers. }\end{array}$ & 87 & 13 & 0 & 0 \\
\hline $\begin{array}{l}\text { The use of digital-based teaching materials in } \\
\text { teaching and learning excites me. }\end{array}$ & 87 & 13 & 0 & 0 \\
\hline $\begin{array}{l}\text { The use of digital-based teaching materials in } \\
\text { teaching and learning will change the way } \\
\text { students learn in my classes. }\end{array}$ & 100 & 0 & 0 & 0 \\
\hline $\begin{array}{l}\text { A digital-based teaching material is not } \\
\text { conducive for learning because it is not easy to } \\
\text { use. }\end{array}$ & 0 & 0 & 63 & 37 \\
\hline $\begin{array}{l}\text { A digital-based teaching material will help } \\
\text { students understand concepts in more effective } \\
\text { ways. }\end{array}$ & 25 & 75 & 0 & 0 \\
\hline $\begin{array}{l}\text { The use of digital-based teaching materials in } \\
\text { teaching and learning will make the students } \\
\text { become more active }\end{array}$ & 75 & 25 & 0 & 0 \\
\hline $\begin{array}{l}\text { The use of digital-based teaching materials in } \\
\text { teaching and learning will stress me out. }\end{array}$ & 0 & 0 & 75 & 25 \\
\hline
\end{tabular}


The findings indicate that teachers have the desire to integrate digital-based teaching materials effectively in the classroom. This is in line with the results of the study of the Cachia and Ferrari (2010) study showed that teachers do combine different resources in their teaching, as well as utilizing various modes of ICT with almost two- thirds claiming to use technologies (63\%) and website (62\%). It can be seen from table II that most of the respondents strongly agree to use digital-based teaching materials in teaching and learning. It is a valuable tool for teachers because (1) It will change the way students learn in their classes, (2) It will make the students become more active, (3) It will help students understand concepts in more effective ways, and (4) It is conducive for learning because easy to use.

The results underline the need for more efforts to be undertaken by the minister of education to improve teachers' readiness to implement digital-based teaching materials. Education stakeholders need to be convinced that teachers' readiness is essential to successful implementation of the digital based teaching materials.

Teachers need to have the skills and confidence in using this technology. This is in line with the study from Cachia and Ferrari's (2010) research; important technologies for learning such as computers (98\%) and educational software (93\%) were ranked as the top technologies. Interactive teaching and learning atmosphere will promote active communication between teachers and students or students with students. The use of digital-based teaching materials in the teaching and learning process aims to improve the quality of teaching and learning.

\section{Obstacles faced by the English teachers in teaching-learning process}

TABLE III. OBSTACLES FACED BY THE ENGLISH TEACHERS IN TEACHING-LEARNING PROCESS

\begin{tabular}{|lccc|}
\hline \multicolumn{1}{|c}{$\begin{array}{c}\text { Survey Items } \\
\text { obstacles faced by the in-service teachers in } \\
\text { teaching-learning process }\end{array}$} & Often & Sometimes & Seldom \\
\hline $\begin{array}{l}\text { Lack of technical support } \\
\text { Lack of time in school }\end{array}$ & 0 & 63 & 37 \\
\hline $\begin{array}{l}\text { Limited knowledge and understanding on } \\
\text { how to integrate digital-based teaching } \\
\text { materials in teaching and learning into } \\
\text { teaching }\end{array}$ & 0 & 75 & 25 \\
\hline $\begin{array}{l}\text { Lack of software or websites that support } \\
\text { teaching and learning }\end{array}$ & 63 & 37 & 0 \\
\hline $\begin{array}{l}\text { Lack of digital-based teaching materials in } \\
\text { teaching and learning in school }\end{array}$ & 87 & 13 & 0 \\
\hline
\end{tabular}

From table III, It can be seen that most of the respondents faced some obstacles during the teaching and learning process. The obstacles that faced by the respondents namely: (1) Lack of technical support, (2) Lack of time in school, (3) Limited knowledge and understanding on how to integrate digital-based teaching materials in teaching and learning into teaching, (4) Lack of software or websites that support 
teaching and learning, and (5) Lack of digital-based teaching materials in teaching and learning in school.

\section{English teacher's perception on the procurement and development of digital- based teaching materials}

The results of interviews on several high school English teachers in Solo Raya related to teachers' perceptions about the procurement of digital books or e-books, namely: (1) the majority of teachers stated about the importance of procurement and utilization of English digital books that follow the development of time to support the learning process in this digital era, (2) the majority of teachers also believe that with the digital book it will be able to improve the effectiveness of the learning process in the classroom, (3) teachers and students will also be challenged to master and operate the use of computer, net book, Gadgets, (4) teachers also expect the provision of a clear, understandable, and interesting English textbook.

The results of interviews with the English teachers in Solo Raya related to the development of digital books or e-books, namely: (1) the majority of teachers stated about the importance of procurement and utilization of English digital books that follow the development era to support the learning process in this digital era, (2) the majority of teachers also believe that with the digital book it will be able to improve the effectiveness of the learning process in the classroom, (3) teachers and students will also be challenged to master and operate the use of computer, netbook, as well as gadgets, (4) teachers also expect a clear, understandable, and interesting English digital book

\section{CONCLUSION AND IMPLICATION}

The findings of the study can be summarized under four headings, which are (1) the English teachers' technical readiness towards digital-based teaching materials, (2) the English teacher's attitude towards digital-based teaching material, (3) the obstacles faced by the English teachers towards the development of digital-based teaching materials, and (4) the English teacher's perceptions towards the development of digital-based teaching materials.

The results reveal that the English teacher's readiness towards digital-based teaching materials is only slightly more than neutral, which implies that the English teachers of senior high school in Solo tend to accept the implementation of digitalbased teaching materials prudently. The results seem similar to research done by Rosnaini and Mohd Arif (2010) where minority group of teachers were knowledgeable on ICT. Another findings indicate that teachers have the desire to integrate digital-based teaching materials effectively in the classroom. This is in line with the results of the study of the Cachia and Ferrari (2010) study showed that teachers do combine different resources in their teaching, as well as utilizing various modes of ICT with almost two- thirds claiming to use technologies (63\%) and website $(62 \%)$. The last is that, the English teachers faced some problems during the teaching and learning process, namely: (1) Lack of technical support, (2) Lack of time in school, (3) Limited knowledge and understanding on how to integrate digitalbased teaching materials in teaching and learning into teaching, (4) Lack of software 
or websites that support teaching and learning, and (5) Lack of digital-based teaching materials in teaching and learning in school.

It can be concluded that the English teacher at senior High School in Solo need intensive training in the use of the digital-based teaching materials to fully support the teaching and learning process. Teachers must have the technical and pedagogical skills to use technology and the willingness to integrate technology in their teaching (Gura \& Percy, 2005). Teachers' professional development programs should be designed to equip teachers with technical skills and pedagogical knowledge to implement the digital curriculum (Al-Awidi \& Aldhafeeri, 2017).

Based on the description above, it is important to develop digital-based teaching materials. Through digital-based teaching materials is expected to reduce the burden of educators in presenting information. It is in line with Singh \& Chan (2014) the teaching methods of all subject areas require a fresh orientation towards a more experiential and student-centered approach supported by interactive ICT multimedia tools and IT or Information Systems (IS) network learning. The teaching materials provided become more concrete and does not depend on information provided educators. Learners can learn according to their needs, abilities, talents and interests.

\section{REFERENCES}

[1] Cachia, R., \& Ferrari, A. (2010). Creativity in schools: A survey of teachers in Europe. Luxembourg: Publications Office of the European Union.

[2] Ertmer, P. A., Ottenbreit-Leftwich, A. T., Sadik, O., Sendurur, E., \& Sendurur, P. (2012). Teacher beliefs and technology integration practices: A critical relationship. Computers and Education, 59(2), 423-435.

[3] Grabe, W., \& Stoller, F. (2002). The nature of reading abilities. Teaching and researching reading, 9-39.

[4] Gura, M., \& Percy, B. (2005). Recapturing technology for education: Keeping tomorrow in today's classrooms, Lanham, Maryland: Scarecrow Education.

[5] Huang, K. L., Chen, K. H., \& Ho, C. H. (2014). Enhancement of reading experience: Users' behavior patterns and the interactive interface design of tablet readers. Library Hi Tech, 32(3), 509-528.

[6] Kamgar, N., \& Jadidi, E. (2016). Exploring the Relationship of Iranian EFL Learners Critical Thinking and Self-regulation with their Reading Comprehension Ability. Procedia-Social and Behavioral Sciences, 232, 776-783.

[7] Pinto, M., Pouliot, C., \& Antonio Cordon-Garcia, J. (2014). E-book reading among Spanish university students. The Electronic Library, 32(4), 473-492. Primary Education.TectumVerlag

[8] Ruggiero, D., \& Mong, C. J. (2015). The teacher technology integration experience: Practice and reflection in the classroom. Journal of Information Technology Education Research, 14, 161-178. Retrieved May 14, 2016 from http://www.informingscience.org/Publications/2227

[9] Sabzian, F. \& Gilakjani, A. P. (2013). Teachers' attitudes about computer technology training, professional de-velopment, integration, experience, anxiety and literacy in English language teaching and learning. International Journal of Applied Science and Technology, 3(1), 67-75.

[10] Singh, T. K. R., \& Chan, S. (2014). Teacher readiness on ICT integration in teaching-learning: A Malaysian case study. International Journal of Asian Social Science, 4, 874-885.

[11] Summaka, M., Baglibel, M., \& Samancioglu, M. (2010). Technology readiness of primary school teachers: A case study in Turkey. Procedia Social and Behavioral Sciences, 2, 2671-2675. 